\title{
Allium sativum antimicrobial potential in fresh cheese
}

\author{
Potencial antimicrobiano de Allium sativum em queijos minas frescal \\ Potencial antimicrobiano de Allium sativum em quesos frescos
}

Received: 02/22/2021 | Reviewed: 03/01/2021 | Accept: 03/05/2021 | Published: 03/14/2021

\author{
Izabela da Silva Milo \\ ORCID: https://orcid.org/0000-0002-1774-4773 \\ Universidade Estadual do Norte do Paraná, Brazil \\ E-mail: izabelamilo@gmail.com \\ Anna Carolina Leonelli Pires de Campos \\ ORCID: https://orcid.org/0000-0003-0222-5732 \\ Universidade Estadual de Londrina, Brazil \\ E-mail: aclpcampos@gmail.com \\ Luciano Netto de Castro Pereira \\ ORCID: https://orcid.org/0000-0002-2426-3978 \\ Universidade Estadual do Norte do Paraná, Brazil \\ E-mail: lucianonettoncp@gmail.com \\ Pamela Anastácio Bertolini \\ ORCID: https://orcid.org/0000-0002-1144-8199 \\ Universidade Estadual do Norte do Paraná, Brazil \\ E-mail: pabertoline@hotmail.com \\ Milena Cremer de Souza \\ ORCID: https://orcid.org/0000-0003-1999-6955 \\ Universidade Estadual do Norte do Paraná, Brazil \\ E-mail: cremermilena@gmail.com \\ Michaela Fernandes Sena \\ ORCID: https://orcid.org/0000-0002-9143-4570 \\ Universidade Estadual do Norte do Paraná, Brazil \\ E-mail: michaelafsena@gmail.com \\ Eder Paulo Fagan \\ ORCID: https://orcid.org/0000-0002-7115-5814 \\ Universidade Estadual do Norte do Paraná, Brazil \\ E-mail: fagan@uenp.edu.br \\ Leopoldo Sussumu Matsumoto \\ ORCID: https://orcid.org/0000-0001-5102-545X \\ Universidade Estadual do Norte do Paraná, Brazil \\ E-mail: leopoldo@uenp.edu.br \\ Erika Cosendey Toledo de Mello Peixoto \\ ORCID: https://orcid.org/0000-0002-9608-4282 \\ Universidade Estadual do Norte do Paraná, Brazil \\ E-mail: emellopeixoto@uenp.edu.br
}

\begin{abstract}
Cheese consumption has shown an important increase throughout the Brazilian territory, being the second most imported product since 2015. Among the different types of cheese, minas frescal represents one of the most popular, due to its simple processing, low cost and high yield. However, its perishability requires refrigeration and relatively fast consumption, thus representing an important limiting factor in commercialization. Aspects such as having a high moisture content, not undergoing maturation, and containing no preservatives, provide favorable conditions for microbiological contamination. Thus, it was aimed to assess the antimicrobial potential of the aqueous suspension of garlic (SAA), in fresh cheese before and after contamination Staphylococcus aureus (ATCC 25923) $10^{5} \mathrm{CFU} \mathrm{mL}^{-1}$. The minimum inhibitory concentration (MIC) was determined by microdilution, and the following treatments were evaluated in quintuplicate: SAa in freeze-dried and fresh forms $(1.5 ; 2.5 ; 5$; and $10 \%)$, negative control treatment (cheese absent contamination), and positive (cheese absent from SAa). After superficial inoculation in Agar Baird Parker, enriched with egg yolk and potassium tellurite, the incubation was performed at $35^{\circ} \mathrm{C}$ for 48 hours. Although SAa in lyophilized and fresh form applied before contamination did not show antibacterial activity, the fresh form applied after contamination showed a MIC equivalent to $2.5 \%$. So, based on the results obtained by the present study, it was possible to conclude that SAa above $2.5 \%$ had antimicrobial properties, thus favoring the conservation of fresh cheese.
\end{abstract}

Keywords: Natural food preservatives; Garlic; Medicinal plants; Natural antimicrobial. 


\section{Resumo}

O consumo de queijos vem apresentando importante aumento em todo território brasileiro, sendo o segundo produto mais importado desde 2015. Dentre os diversos tipos de queijos, o minas frescal representa um dos mais populares, devido ao seu processamento simples, baixo custo e alto rendimento. Porém, sua perecibilidade exige armazenamento sob refrigeração e consumo relativamente rápido, representando assim importante fator limitador na comercialização. Aspectos como possuir alto teor de umidade, não sofrer maturação, e não conter conservantes, propiciam condições favoráveis à contaminação microbiológica. Dessa forma, objetivou-se avaliar o potencial antimicrobiano da suspensão aquosa de alho (SAa), em queijo minas frescal antes e após contaminação por Staphylococcus aureus (ATCC 25923) $10^{5}$ UFC mL $\mathrm{mL}^{-1}$. A concentração inibitória mínima (MIC) foi determinada por microdiluição, e os seguintes tratamentos foram avaliados em quintuplicada: SAa nas formas liofilizada e in natura $(1,5 ; 2,5 ; 5$; e $10 \%)$, tratamento controle negativo (queijo ausente de contaminação), e positivo (queijo ausente de SAa). Após inoculação superficial em meio Agar Baird Parker, enriquecido com de gema de ovo e telurito de potássio, a incubação foi realizada a $35^{\circ} \mathrm{C}$ por 48 horas. Embora a SAa na forma liofilizada e in natura aplicada antes da contaminação não tenham apresentado atividade antibacteriana, a forma in natura aplicada após contaminação apresentou MIC equivalente a 2,5\%. Dessa forma, a partir dos resultados obtidos pelo presente estudo, foi possível concluir que SAa a partir de $2,5 \%$, apresentou propriedade antimicrobiana, podendo favorecer assim a conservação do queijo frescal.

Palavras-chave: Conservantes naturais de alimentos; Alho; Plantas medicinais; Antimicrobiano natural.

\section{Resumen}

El consumo de queso ha mostrado un aumento importante en todo el territorio brasileño, siendo el segundo producto más importado desde 2015. Entre los diversos tipos de queso, las minas frescal representa uno de los más populares, por su simple elaboración, bajo costo y alto rendimiento. Sin embargo, su perecibilidad requiere almacenamiento refrigerado y un consumo relativamente rápido, lo que representa un importante factor limitante en la comercialización. Aspectos como tener un alto contenido de humedad, no madurar y no contener conservantes, proporcionan condiciones favorables para la contaminación microbiológica. Así, el objetivo fue evaluar el potencial antimicrobiano de la suspensión acuosa de ajo (SAa), en queso minas frescal antes y después de la contaminación por Staphilococcuss aureus (ATCC 25923) $10^{5}$ UFC mL-1. La concentración mínima inhibitoria (CMI) se determinó por microdilución y se evaluaron los siguientes tratamientos por quintuplicado: SAa en forma liofilizada y fresca (1,5; 2,$5 ; 5 ;$ y 10\%), tratamiento control negativo (queso ausente contaminación) y positivo (queso ausente de SAa). Después de la inoculación superficial en medio Agar Baird Parker, enriquecido con yema de huevo y telurito potásico, la incubación se realizó a $35^{\circ} \mathrm{C}$ durante 48 horas. Aunque el SAa en forma fresca y liofilizada aplicada antes de la contaminación no mostró actividad antibacteriana, la forma fresca aplicada después de la contaminación mostró una CIM equivalente al 2,5\%. Así, SAa del 2,5\%, presentó propiedades antimicrobianas, favoreciendo así la conservación del queso fresco.

Palabras clave: Conservantes alimentarios naturales; Ajo; Plantas medicinales; Antimicrobiano natural.

\section{Introduction}

Cheese consumption has shown an important increase throughout the Brazilian territory, being the second most imported product since 2015. Among the different types of cheese, minas frescal represents one of the most popular, due to its simple processing, low cost and high yield (Gouvea et al., 2017). Nowadays it is highly valued mainly for its nutritional aspects. Its fast digestibility, low fat and sodium content, make the fresh cheese often recommended for restrictive diets. However, its perishability requires storage under refrigeration and relatively fast consumption, thus representing an important limiting factor in commercialization.

Usually fresh cheese is produced using pasteurized milk added to the rennet, resulting in enzymatic coagulation and dough formation. This cheese, because it does not undergo maturation, preserves a high moisture content. Moreover, its marketing in natura does not make use of preservatives, compromising the product as to its validity to consumption, which should be fast. Thus, these aspects provide favourable conditions for microbiological contamination (Bastos et al., 2020); which in turn can occur even when preserved and manipulated correctly (Silva et al., 2019). However, factors related to inadequate forms of production and storage of the product at temperatures that favour bacterial growth should be considered (Zocche et al., 2012). 
Contamination by microorganisms can determine changes in sensory characteristics (taste and odor), affecting commercialization, besides to being a risk to public health, the possibility of food poisoning and toxification. Thus, cheese that is unfit for consumption is a recurring problem, and these contaminated products continue to be found in commerce.

The presence of microorganisms such as coagulase positive Staphylococci, fecal coliforms, Salmonella typhimurium, Staphylococcus aureus, and aerobic mesophilic, molds, yeasts, among others, is still often registered (Oliveira et al., 2017; Queiroz et al., 2017; Boas et al., 2020; Camargo et al., 2020; Motta \& Farias, 2020). On the other hand, consumers are increasingly aware of food safety, looking for natural, healthy foods that are free of medicinal residues (Sampaio \& Junior, 2018). Thus, research on natural preservatives has gained prominence in recent years (Barros et al., 2020; Coutinho et al., 2020; Mendonça et al., 2020; Souza et al., 2020).

Some condiment plants, by also having medicinal properties, may represent important natural alternative to chemical preservatives for food preservation, because even in high concentrations usually do not determine health risk (Freire et al., 2011; Galo et al., 2018; Coutinho et al., 2020). The increase in the use of condiment plants in recent decades, is mainly due to factors such as the appreciation of the use of natural products (Galo et al., 2018), among which Allium sativum (Horita, 2016) stands out.

Allium sativum L. is a condiment consumed and appreciated worldwide. Popularly known as garlic it is also considered nutraceutical by the National Health Surveillance Agency (ANVISA) - RDC nº 26 of may 13 of 2014 (Brasil, 2014). Its benefit and its wide use are mainly due to the presence of phenolic and organosulfur compounds, responsible for its antioxidant action, aroma and flavor (El-Sayed et al., 2017; Lanzotti et al., 2014). Its antimicrobial activity is mainly associated with the presence of allicin, which possibly acts by the cellular breakdown of microorganisms (Li et al., 2016) and oxidative stress (Rabinkov et al., 1998). The essential oil of garlic showed antibacterial action against Staphylococcus aureus, Escherichia coli, Bacillus subtilis (Guo, 2014), Staphylococcus choleraesuis (Coutinho et al., 2020), besides the antifungal action on Penicillium funiculosum (Li et al., 2014). Raw garlic inhibited Helicobacter pylori (Zardast et al., 2016), and in the form of nanovesicles it was effective against Listeria monocytogenes (Pinilla et al., 2017). Thus, the present work aimed to evaluate the antimicrobial activity of Allium sativum, as aqueous suspension (SAa) and in natura (Ain), on fresh cheeses contaminated with S. aureus (ATCC 25923).

\section{Methodology}

\section{Production of the aqueous suspension of garlic}

For the production of the $10 \%(\mathrm{~m} / \mathrm{v})$ Allium sativum (SAa) aqueous suspension, $87.5 \mathrm{~g}$ of peeled and macerated garlic bulbs were added to $875 \mathrm{~mL}$ of ultrapure Milli-Q water. Subsequently, the suspension was ground in a blender for approximately three minutes, filtered on household filter paper, and immediately used for evaluation of the different treatments. The mean pH of the suspension was 5.6 (Rodríguez García \& Peraza Echeverría , 2019).

\section{Preparation of the Staphylococcus aureus suspension (ATCC 25923)}

For the production of the $S$. aureus solution used in the minimum inhibitory concentration (MIC) test, the bacteria were grown in Baird Parker Agar. Subsequently, the colonies were diluted in 0.85\% peptone saline to the concentration of $10^{8}$ UFC/mL (McFarland Scale 1) (Garcia, 2010). Subsequently, $10 \mu \mathrm{L}$ of this solution was added to $990 \mu \mathrm{L}$ of Mueller Hinton broth up to $10^{5} \mathrm{CFU} / \mathrm{mL}$. 


\section{Minimum Inhibitory Concentration (MIC)}

The determination of the minimum inhibitory concentration (MIC) against Staphylococcus aureus (ATCC 25923) was evaluated in triplicate using a microdilution method according to Clinical and Laboratory Standards Institute (CLSI, 2015). For this, polystyrene plates with 96 flats bottom wells were used. $50 \mu \mathrm{L}$ of Mueller Hinton broth, and $50 \mu \mathrm{L}$ of SAa were added. This solution was then successively diluted and subsequently $50 \mu \mathrm{l}$ of the $\mathrm{S}$. aureus solution was added.

After incubation in a bacteriological oven for 24 hours at $35^{\circ} \mathrm{C}$, the presence of turbidity of the medium and formation of precipitate, corresponding to bacterial growth, were evaluated.

\section{Preparation of cheeses}

The cheeses were produced and inoculated according to the protocols of Soares et al. (2008) and Campos et al. (2019). The milk was pasteurized in a water bath until heating to $65^{\circ} \mathrm{C}$ and held for 30 minutes, then cooled to $38^{\circ} \mathrm{C}$ and added with $0.5 \mathrm{~mL}$ of calcium chloride per liter along with one $\mathrm{ml}$ of rennet per liter. After 50 minutes rest, the mass of the cubes was cut with $\mathrm{a} \mathrm{cm}^{3}$, homogenizing the mass were performed for five minutes and rest for five minutes. Then the dough was placed in the forms for further cooling at $4^{\circ} \mathrm{C}$.

After 24 hours in refrigeration the pieces of cheese were removed from the forms and the surface contamination by immersion was carried out. For this, the bacteria were cultured in $25 \mathrm{~mL}$ of Brain Heart Infusion (BHI) liquid medium, incubated at $37^{\circ} \mathrm{C}$ for 24 hours. The culture was seeded in Baird Parker Agar and again incubated at $37^{\circ} \mathrm{C}$ for 24 hours. Colonies were then removed from the plate and diluted in peptone water, and then compared to the McFarland scale at 1.0x $10^{8}$ $\mathrm{CFU} / \mathrm{mL}$. Then this solution was used for the contamination of the cheeses, which were immersed in it for approximately two minutes each piece, with the exception of the negative control.

Fresh cheeses were individually made by the addition of 2 liters of pasteurized milk at $125 \mathrm{~mL}$ (SAa125), $250 \mathrm{~mL}$ (SAa250) and $500 \mathrm{~mL}$ (SAa500) from SAa, totaling three pieces of fresh cheese, with SAa concentrations of $0.58 \% 1.11 \%$ and $2 \%$, respectively. The following treatments were evaluated: SAa125, SAa250, SAa500, cheese without SAa that corresponded to the negative control $(\mathrm{CN})$, and cheese added to S. aureus ATCC 25923, which corresponded to the control (CT). Three runs were performed in order to obtain three experimental units of each treatment.

For the treatments with garlic in natura (Ain), 50 grams of peeled and chopped garlic were added to each liter of milk, totaling three treatments: fresh garlic cheese, garlic-free cheese corresponding to the negative control $(\mathrm{CN})$ and cheese contaminated with S. aureus that corresponded to the control (CT).

\section{Microbiological analyzes}

Aliquots of $10 \mathrm{~g}$ of each sample (cut into a cuticle) containing $90 \mathrm{~mL}$ of $0.9 \% \mathrm{NaCl}$ solution as the diluent were used. The sample was then transferred to sterile plastic bags made of Nasco WHIRL-PAK® low density polyethylene and homogenized in Stomacher 400 for 60 seconds. From the initial dilution at $10^{-1}$, a series of decimal dilutions were prepared up to the dilution of $10^{-4}$, using test tubes with $9.0 \mathrm{~mL}$ of $0.9 \% \mathrm{NaCl}$ solution. From each of the dilutions of the examined cheese samples, $0.1 \mathrm{~mL}$ was transferred to Baird Parker Agar surface enriched with egg yolk and potassium tellurite in Petri dishes. The inoculum was then spread over the entire surface of the medium with the aid of a Drigalsky loop and the plates incubated at $36^{\circ} \mathrm{C}$ for 48 hours in a bacteriological oven.

After incubation, we counted the number of colonies that presented characteristics typical of $S$. aureus as a bright black color, with a white precipitation zone around it and surrounded by transparent halo. The counted colonies were multiplied by factor 10, and by the reciprocal of the dilution corresponding to the counting plate, thus obtaining the value of the $S$. aureus count per gram of cheese. The result was expressed in CFU/g. 
The microbiological analyzes described above were performed one day after cheesemaking (D1) and after days D5, D10 and D15 in order to evaluate the effect of SAa since the expiration date of a fresh cheese usually corresponds to 7 to 10 days after the date of manufacture. At the same time, color, odor, softness and texture characteristics were also evaluated using a descriptive method (Teixeira, 2009).

\section{Results and Discussion}

For the MIC test, the minimum concentration of SAa in vitro capable of inhibiting any bacterial growth was $1.25 \%$. SAa demonstrated antimicrobial capacity against S. aureus. Saha et al. (2016) evaluated the MIC of aqueous extract of Allium sativum against $S$. aureus and E. coli observing the concentrations of $400 \mu \mathrm{g} / \mathrm{mL}$ and $700 \mu \mathrm{g} / \mathrm{mL}$ as MIC, respectively.

For the first cheese processing, treatments SAa250 and SAa500 demonstrated a decrease in the bacterial count of $0.26 \%$ and $2.40 \%$ respectively (Figure 1). However, the treatment of SAa125 showed an increase of $0.7 \%$.

Figure 1. Staphylococcus aureus count (log CFU g-1) in fresh cheese during 15 days of storage.

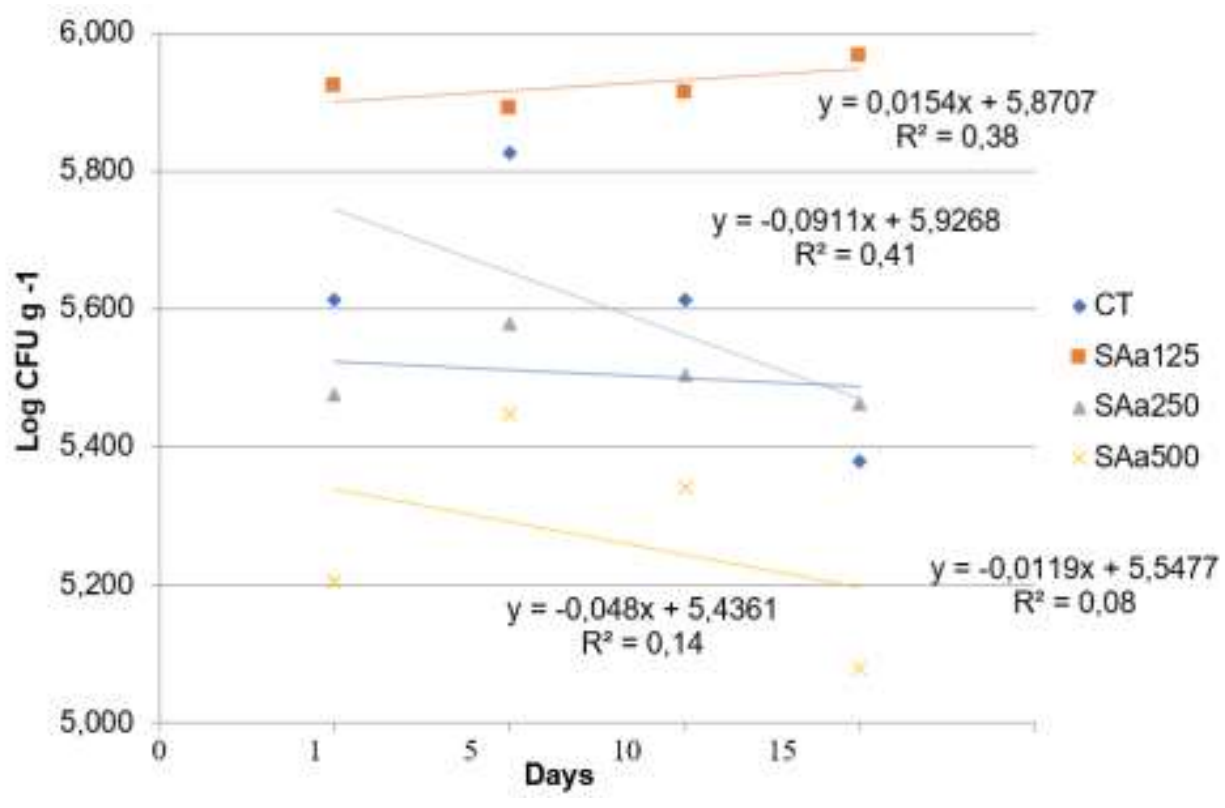

Source: Authors.

This increase may be the result of a possible contamination of the SAa125 aqueous solution with $S$. aureus prior to addition to the cheese or of inefficiency of the aqueous suspension at that concentration. For garlic in natura, there was a decrease of $4.98 \%$ in the bacterial count, which can be verified in Table 1.

Table 1. Count of colony forming units in log per gram of cheese analyzed during storage days.

\begin{tabular}{lll}
\hline & CT & Ain \\
\hline Day 1 & 4,929 & 5,389 \\
Day 5 & 5,008 & 5,217 \\
Day 10 & 4,770 & 5,120 \\
\hline
\end{tabular}

CT: control

Ain: cheese with garlic in natura $(50 \mathrm{~g} /$ liter of milk used) 
Source: Authors.

Fresh garlic had better results compared to SAa, possibly due to the concentration of alicina, the main antimicrobial component (Corzo-Martínez et al., 2007) that is diluted in aqueous solution.

Yadav et al. (2015) found that 50\% fresh garlic juice has antibacterial properties against Gram-positive and Gramnegative organisms such as Escrerichia coli, Staphylococcus aureus, Klebsiella pneumonia, Proteus mirabilis and Pseudomonas aeruginosa each of 4-8\% with the exception of $P$. aeruginosa which is $4-16 \%(\mathrm{v} / \mathrm{v})$.

However, Dantas et al. (2018) evaluating the hydroalcoholic and glycolic extract of A. sativum, both at 30\% and 70\%, in the in natura and dry forms, did not record S. aureus antimicrobial action, evidencing that the solvent choice is important for the desired results. Differently, Alli et al. (2011) and Daka (2011) verified antibacterial action of garlic extract at $12.5 \%$ in $S$. aureus clinical isolates.

Deresse (2010) evaluated the antimicrobial activity of the aqueous extract of garlic on 30 clinical isolates of S. aureus, checking the concentration of $7.5 \mathrm{mg} / \mathrm{mL}$ as MIC. The same work revealed that the activity of the extract is sensitive to heat due to the results presented after autoclaving the extract at a temperature of $121^{\circ} \mathrm{C}$ for 15 minutes where the antimicrobial capacity was lost, for the material at room temperature or refrigerated, the antimicrobial capacity remained. However, when using fresh garlic this capacity is higher. This may be due to the greater presence of allicin, which totally inhibits RNA synthesis and partially the synthesis of DNA and bacterial proteins (Feldberg et al., 1988).

In the second cheese processing, all treatments were efficient to decrease the bacterial count, decreasing by $9.44 \%$, 7.62\% and 6.67\% respectively (Figure 2); corroborating with Nejad et al. (2014).

Figure 2. Staphylococcus aureus count (log CFU g-1) in fresh cheese during 15 days of storage.

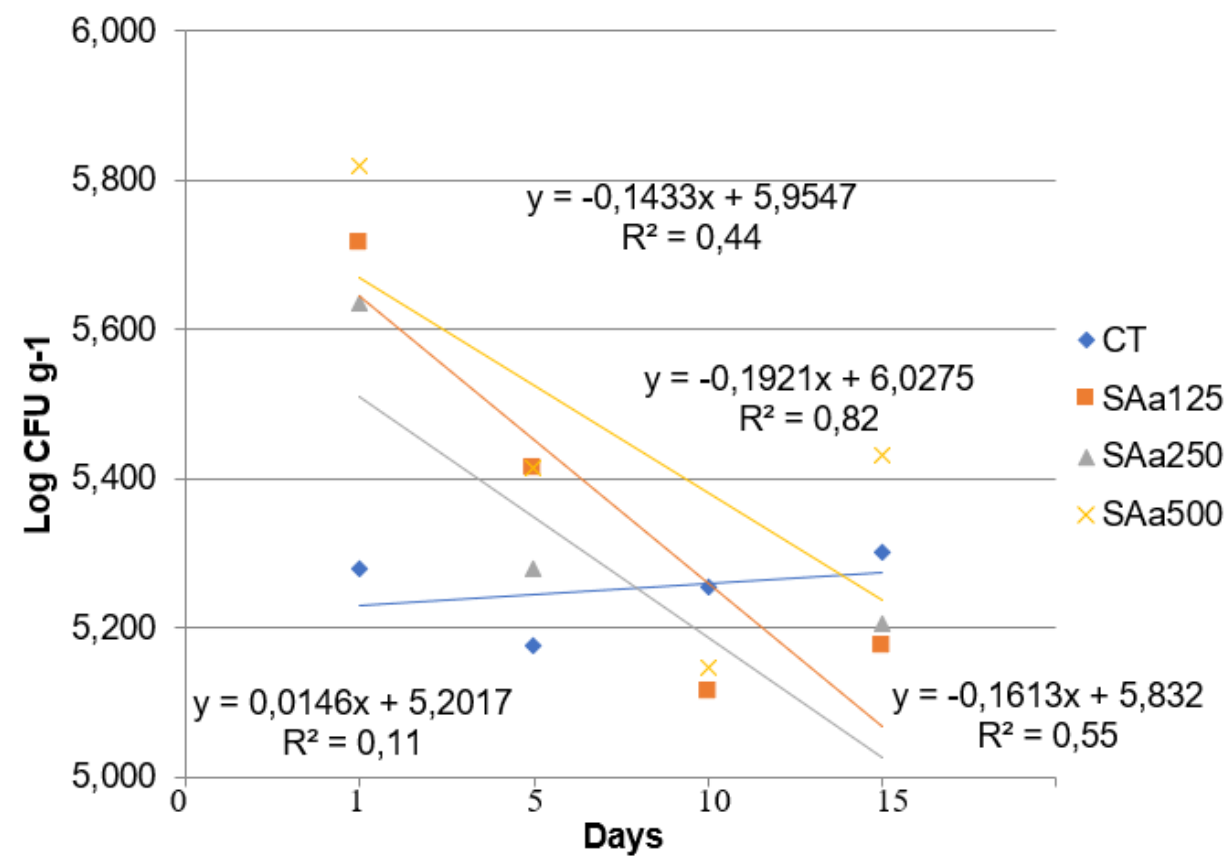

Source: Authors.

They evaluated the antimicrobial effect of aqueous extract of garlic (500g to $200 \mathrm{~mL}$ of saline solution) on hamburger with three different amounts of extract: $1 \mathrm{~mL}, 2 \mathrm{~mL}$ and $3 \mathrm{~mL}$, noting that in all amounts during the storage period the extract was able to inhibit $S$. aureus growth. For garlic in natura, there was a decrease of $10.01 \%$ of the microorganisms, represented in Table 2. 
Research, Society and Development, v. 10, n. 3, e21610313213, 2021

(CC BY 4.0) | ISSN 2525-3409 | DOI: http://dx.doi.org/10.33448/rsd-v10i3.13213

Table 2. Count of colony forming units in log per gram of cheese analyzed during storage days.

\begin{tabular}{lll}
\hline$\square$ & CTo & Aino \\
\hline Day-10 & 4,9950 & 5,1810 \\
Day-50 & 4,4910 & 4,8260 \\
Day-100 & $4,414 \div$ & 4,6620 \\
\hline
\end{tabular}

CT: control

Ain: cheese with garlic in natura $(50 \mathrm{~g} / \mathrm{liter}$ of milk used)

Source: Authors.

In the third cheese processing, the decrease in the bacterial count was $16.78 \%, 17.64 \%$ and $13.01 \%$ for the treatments SAa125, SAa250 and SAa500 respectively (Figure 3).

Figure 3. Staphylococcus aureus count (log CFU g-1) in fresh cheese during 15 days of storage.

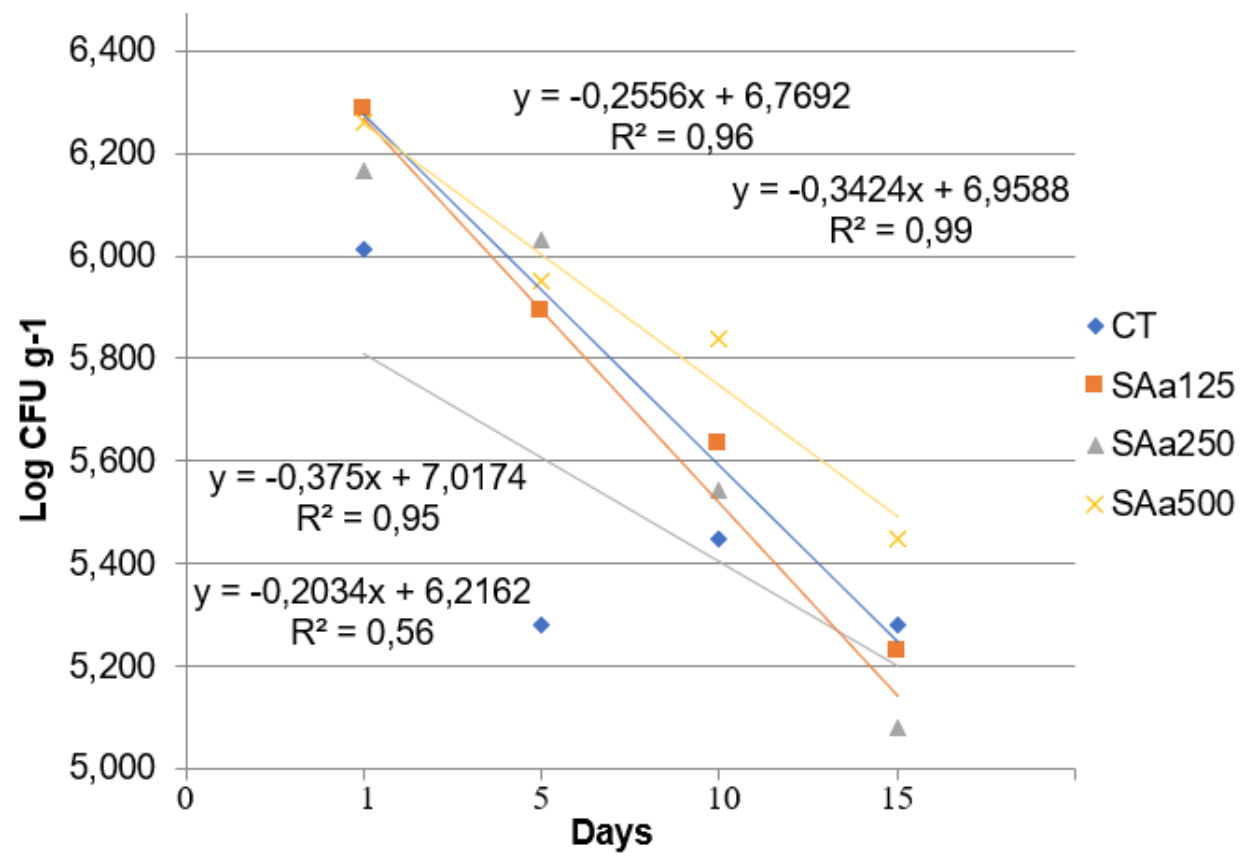

Source: Authors.

However, it is verified that the control cheese also had a reduction in the microbial count. Because it does not contain aqueous solution of garlic, it can be reported that the storage temperature (less than $5^{\circ} \mathrm{C}$ ) can be a contributing factor for the reduction of the microbial load. For garlic in natura, there was a decrease of $3.72 \%$ in the bacterial count, and it can be observed in Table 3. 
Table 3. Count of colony forming units in log per gram of cheese analyzed during storage days.

\begin{tabular}{lll}
\hline & CT & Ain \\
\hline Day 1 & 4,770 & 5,045 \\
Day 5 & 4,568 & 4,869 \\
Day 10 & 4,447 & 4,857 \\
\hline
\end{tabular}

CT: control

Ain: cheese with garlic in natura $(50 \mathrm{~g} /$ liter of milk used)

Source: Authors.

It is observed that the best treatment is SAa250 in which there was a mean decrease in the S. aureus count of $8.48 \%$, followed by the SAa500 treatment in which the mean count decrease was $7.36 \%$.

Shan et al. (2011) evaluated the antimicrobial effects of five hydroalcoholic extracts (cinnamon, oregano, clove, pomegranate peel and grape seed) against Listeria monocytogenes, Staphylococcus aureus and Salmonella enterica in cheddar cheese. The clove extract showed the highest antibacterial and antioxidant activity, showing the potential of the use of spices to favor the stability and conservation of the cheese during the storage period.

The concentration levels of the extracts may vary according to the species of Allium sp. Their secondary metabolites produced in the different countries, different ways of processing the raw material, as well as the innocuous concentrations for the test (Deresse, 2010).

The content of lipids and proteins in foods is a factor that affects the efficiency of natural antimicrobial agents, due to the possibility of a physical protection barrier, preventing the contact of the compound with the microorganism, thus reducing the effectiveness of the extract or essential oil (Gutierrez et al., 2008). Cava et al. (2007) verified that the antimicrobial activity of essential oils of clove and cinnamon was impaired by the presence of fat in the milk in comparison to the skim milk, evidencing that it is necessary to study the interaction of oils and extracts with food composition.

Hassanien et al. (2014) demonstrated that, in culture medium, $0.1 \%$ cumin oil was able to inhibit the growth of $L$. monocytogenes, S. aureus, S. enteritidis and E. coli. cheeses this concentration was not efficient in inhibiting $S$. aureus and $L$. monocytogenes. Emphasizing that the concentrations of extracts and essential oils vary according to the microorganism and its particular sensitivity.

Cheese is a nutritionally rich food, because it has high levels of proteins and lipids. Due to this feature, to achieve an efficient degree of microbiological inhibition, the concentrations of natural compounds to be added should be higher than the concentrations found in in vitro tests (Moro et al., 2015).

Mahajan et al. (2016) studied the use of pine needle extract (Cedrus deodara (Roxb.) Loud.) in kalari cheese (a variety of hard and dry cheese typical of India). They found a decrease in the degradation of proteins and fats, improving the conservation during the storage period under refrigeration.

Gouvea et al. (2017) in a study on the addition of plant extracts and essential oils as antimicrobials in cheeses show that extracts and oils from medicinal plants such as oregano, cumin, pepper, rosemary and thyme have satisfactory in vitro antimicrobial activity against contaminating cheese pathogens (Caleja et al., 2015), representing an important alternative for the conservation of these products. However, in vitro results should not be considered as strictly true for food, since there is a great complexity of the food matrix and also external and internal interference factors of the food itself (Calo et al., 2015).

Regarding the characteristics of the cheeses, the coloring from the fifth day after application of the treatments, ceased to be white, becoming gradually yellowish, and over time the yellow coloration was predominant in all treatments, which may 
have been favored by $S$. aureus contamination. The yellowish coloration ends up harming the acceptance of cheese consumption, even when the product is still in the shelf life (Dias et al., 2012).

Initially, the cheeses presented characteristic garlic odor in a weak and subtle way. This aspect is of extreme relevance, since it does not strongly compromise the taste of the food. In general, flavors and odors predominant in food, are not desired in the gastronomy, as they compromise the balance of the delicacy. When using aromatic and flavoring plants, it is intended to associate aromas in order to enhance the flavor of the food produced in a harmonious way. Flavors and flavors excessively preponderant, in a way, are undesired by jumping and thus compromising consumer acceptance (Nascimento, 2016).

Regarding texture and softness, all cheeses submitted to different treatments over time were gradually becoming parched and hardened, with cracks on their surface.

\section{Conclusion}

Allium sativum presented antimicrobial activity against Staphylococcus aureus, both in aqueous and in natura suspension form. Therefore, it was possible to verify the antimicrobial activity of garlic in fresh cheese, contributing not only to its storage but also to its flavor, representing a differential for the product and thus favoring its commercialization. Regarding future perspectives, the next studies should take into account the need to promote the greatest possible control of the antimicrobial action of garlic on cheese. However, at the same time, it is necessary to consider the palatability of the product, so as not to compromise the consumer acceptance.

Further studies are needed to confirm the antimicrobial activity of the aqueous extract of Allium sativum in natura, in order to better verify its effects against other contaminating microorganisms in cheese.

\section{Acknowledgments}

This study was financed in part by the Coordenação de Aperfeiçoamento de Pessoal de Nível Superior Brasil (CAPES) - Finance Code 001.

\section{References}

Alli, J. A., Boboye, B. E., Okonko, I. O., Kolade, A. F. \& Nwanze, J. C. (2011). In-vitro assessments of the effects of garlic (Allium sativum) extract on clinical isolates of Pseudomonas aeruginosa and Staphylococcus aureus. Advances in Applied Science Research, 4(2), 25-36.

Bastos, R. B., Martins, O. A. \& Raghiante, F. (2020). Hygienic-sanitary quality of fresh Minas cheese: a review. Revista Brasileira de Higiene e Sanidade Animal, 14(3), 1-12.

Boas, A. F. V., Belpiede, E. L. S., da Silva, N. R. F., da Silva, M. F., \& Veiga, S. M. O. M. (2020). Qualidade microbiológica de queijos minas frescal artesanais e industrializados. Brazilian Journal of Development, 6(10), 83536-83552.

Brasil. (2014). Agência Nacional de Vigilância Sanitária (ANVISA) - RDC nº 26 de 13 de maio 2014.

Caleja, C., Barros, L., Antonio, A. L., Ciric, A., Sokovic, M., Oliveira, M. B. P. P., Buelga, C. \& Ferreira, I. C. F. R. (2015). Foeniculum vulgare Mill. as natural conservation enhancer and health promoter by incorporation in cottage cheese. Journal of Functional Foods, 12, 428-438. https://doi.org/10.1016/j.jff.2014.12.016

Calo, J. R., Crandall, P. G., O’Brvan, C. A. \& Ricke, S. C. (2015). Essential oils as antimicrobials in food systems - A review. Food Control, 54, 111-119. https://doi.org/10.1016/j.foodcont.2014.12.040

Camargo, A. C. B., Jacinto, I. P., de Paiva, J. L., de Paula, J. M., Fação, L. R., Alves, L. G. K., \& Mattos, M. C. D. (2020). Qualidade microbiológica do queijo tipo minas "frescal”" comercializado na cidade de Fernandópolis-SP. Brazilian Journal of Health, 3(4), 10370-10382.

Campos, A. C. P., Ribeiro, C. G. G., Panagio, L. A., Fagan, E. P., Kobayashi, R. K. T. \& Nakazato, G. (2019). Patent: Processo de aplicação de óleo essencial de orégano como antimicrobiano no processo de fabricação de queijos e seu produto resultante. INPI- Instituto Nacional da Propriedade Industrial. Deposited in $05 / 30 / 2019$.

Cava, R., Nowak, E., Taboada, A., \& Marin-Iniesta, F. (2007). Antimicrobial activity of clove and cinnamon essential oils against Listeria monocytogenes in pasteurized milk. Journal of food protection, 70(12), 2757-2763. https://doi.org/10.4315/0362-028x-70.12.2757 
Clinical and Laboratory Standards Institute Performance standards for antimicrobial susceptibility testing. Clinical and Laboratory Standards Institute: Wayne, PA Clinical and Laboratory Standards Institute, 2015.

Corzo-Martínez, M., Corzo, N. \& Villamiel, M. (2007). Biological properties of onions and garlic. Trends in Food Science \& Technology, 18(12), 609-25. https://doi.org/10.1016/j.tifs.2007.07.011

Daka, D. (2011). Antibacterial effect of garlic (Allium sativum) on Staphyloccus aureus: An in vitro study. African Journal of Biotechnology, 4 (10), 666-669.

Deresse, D. (2010). Antibacterial Effect of Garlic (Allium sativum) on Staphylococcus aureus: An in vitro Study. Asian Journal of Medical Sciences, 2(2), 6265 .

Dias, Nayane Aparecida Araújo, Lara, Suzana Borges, Miranda, Lucilene Soares, Pires, Ivy Scorzi Cazelli, Pires, Christiano Vieira, \& Halboth, Nadia Veronica. (2012). Influence of color on acceptance and identification of flavor of foods by adults. Food Science and Technology, 32(2), 296-301. Epub May 29, 2012.https://doi.org/10.1590/S0101-20612012005000059

El-Sayed, H. S., Chizzola, R., Ramadan, A. A., \& Edris, A. E. (2017). Chemical composition and antimicrobial activity of garlic essential oils evaluated in organic solvent, emulsifying, and self-microemulsifying water based delivery systems. Food Chemistry, 221, 196-204. https://doi.org/10.1016/j.foodchem.2016.10.052.

EMBRAPA - Empresa Brasileira de Pesquisa Agropecuária - Embrapa Gado de Leite (CNPGL). Anuário de leite 2020. São Paulo, 2020.

Feldberg, R. S., Chang, S. C., Kotik, A. N., Nadler, M., Neuwirth, Z., Sundstrom, D. C., \& Thompson, N. H. (1988). In vitro mechanism of inhibition of bacterial cell growth by allicin. Antimicrobial Agents and Chemotherapy, 32(12), 1763-1768. https://doi.org/10.1128/aac.32.12.1763

Freire, J. M., Cardoso, M. G., Batista, L. R., Andrade, M. A. \& Lima, R. K. (2011). Controle microbiológico de alimentos utilizando óleos essenciais de Pimpinela anisum (erva-doce). Higiene Alimentar, 25, 154-158.

Galo, G. T. (2018). Estudo da extração da quercetina a partir da cebola roxa (Allium ceppa l.) e seu uso como conservante alimentar natural. The Journal of Engineering and Exact Sciences, 4(1), 0153-0162.

Garcia, L. (2010). Preparation of Routine Media and Reagents Used in Antimicrobial Susceptibility Testing. In Clinical Microbiology Procedures Handbook, 3rd Edition. ASM Press, Washington, DC, 181-201. 10.1128/9781555817435.ch5.14.

Gouvea, Fabiola dos Santos, Rosenthal, Amauri, \& Ferreira, Elisa Helena da Rocha. (2017). Plant extract and essential oils added as antimicrobials to cheeses: a review. Ciência Rural, 47(8), e20160908..https://doi.org/10.1590/0103-8478cr20160908

Guo Y. (2014). Experimental study on the optimization of extraction process of garlic oil and its antibacterial effects. African journal of traditional, complementary, and alternative medicines: AJTCAM, 11(2), 411-414. https://doi.org/10.4314/ajtcam.v11i2.27

Gutierrez, J., Barry-Ryan, C., \& Bourke, P. (2008). The antimicrobial efficacy of plant essential oil combinations and interactions with food ingredients. International Journal of Food Microbiology, 124(1), 91-97. https://doi.org/10.1016/j.ijfoodmicro.2008.02.028

Lanzotti, V., Scala, F. \& Bonanomi, G. (2014). Compounds from Allium species with cytotoxic and antimicrobial activity. Phytochemistry Reviews, 13, 769791. https://doi.org/10.1007/s11101-014-9366-0

Li, W. R., Shi, Q. S., Liang, Q., Huang, X. M., \& Chen, Y. B. (2014). Antifungal effect and mechanism of garlic oil on Penicillium funiculosum. Applied microbiology and biotechnology, 98(19), 8337-8346. https://doi.org/10.1007/s00253-014-5919-9

Li, W. R., Shi, Q. S., Dai, H. Q., Liang, Q., Xie, X. B., Huang, X. M., Zhao, G. Z., \& Zhang, L. X. (2016). Antifungal activity, kinetics and molecular mechanism of action of garlic oil against Candida albicans. Scientific reports, 6, 22805. https://doi.org/10.1038/srep22805

Hassanien, M. F., Mahgoub, S. A., \& El-Zahar, K. M. (2014). Soft cheese supplemented with black cumin oil: Impact on food borne pathogens and quality during storage. Saudi Journal of Biological Sciences, 21(3), 280-288. https://doi.org/10.1016/j.sjbs.2013.10.005

Horita, C. N., Farias-Campomane, A. M., Barbosa, T. S., Esmerino, E. A., Gomes da Cruz, A., Bolini, H. M. A., Meireles, M. A. A. \& Pollonio, M. A. R. (2016). The antimicrobial, antioxidant and sensory properties of garlic and its derivatives in Brazilian low-sodium frankfurters along shelf-life. Food Research International, 84, 1-8. https://doi.org/10.1016/j.foodres.2016.02.006

Mahajan, D., Bhat, Z. F. \& Kumarc, S. (2016). Pine needles (Cedrus deodara (Roxb.) Loud.) extract as a novel preservative in cheese. Food Packaging and Shelf Life, 7, 20-25. https://doi.org/10.1016/j.fpsl.2016.01.001

Moro, A., Librán, C. M., Berruga, M. I., Carmona, M., \& Zalacain, A. (2015). Dairy matrix effect on the transference of rosemary (Rosmarinus officinalis) essential oil compounds during cheese making. Journal of the Science of Food and Agriculture, 95(7), 1507-1513. https://doi.org/10.1002/jsfa.6853

Motta, B. C. \& Farias, L. M. (2020). Determinação da qualidade físico-química e microbiológica do queijo minas frescal artesanal comercializado em uma cidade da Zona da Mata Mineira. Saúde dinâmica, 2(1), 45-65.

Nascimento, M. G. \& Prato, T. S. (2016). Influência da cor e do odor na discriminação do sabor de um produto. Anais do XXV Congresso Brasileiro de Ciência e Tecnologia de Alimentos.

Oliveira, A., Kurihara, R., Silva, F., Silva, F., Ribeiro Júnior, J., \& Beloti, V. (2017). Condições Higiênico-Sanitárias Da Produção De Queijos Tipo Mussarela E Minas Frescal Comercializados No Norte Do Paraná. Revista do Instituto de Laticínios Cândido Tostes, 72(1), 40-47. https://doi.org/10.14295/22386416.v72i1.556

Queiroz, Murilo Mariz, Rossi, Bruna Fernanda, Castilho, Ivana Giovannetti, \& Rall, Vera Lucia Mores. (2017). Hygienic-sanitary quality of Minas fresh cheese sold in the city of Botucatu, São Paulo. Arquivos do Instituto Biológico, 84, e0292016. https://doi.org/10.1590/1808-1657000292016 
Research, Society and Development, v. 10, n. 3, e21610313213, 2021

(CC BY 4.0) | ISSN 2525-3409 | DOI: http://dx.doi.org/10.33448/rsd-v10i3.13213

Pinilla, C. M., Noreña, C. P., \& Brandelli, A. (2017). Development and characterization of phosphatidylcholine nanovesicles, containing garlic extract, with antilisterial activity in milk. Food Chemistry, 220,470-476. https://doi.org/10.1016/j.foodchem.2016.10.027

Rabinkov, A., Miron, T., Konstantinovski, L., Wilchek, M., Mirelman, D., \& Weiner, L. (1998). The mode of action of allicin: trapping of radicals and interaction with thiol containing proteins. Biochimica et Biophysica Acta, 1379(2), 233-244. https://doi.org/10.1016/s0304-4165(97)00104-9

Rodríguez García, C. M., Peraza Echeverría, L. L. P. E. (2019). Preparation of aqueous extracts of plants. Protocols.io. Https://dx.doi.org/10.17504/pr otocols.io.szwef7e

Saha, S. K., Saha, S., Akhter, S. M., Khatun, S., Islam, M. M., \& Roy, P. (2016). In Vitro Determination of Minimum Inhibitory Concentration of Aqueous Garlic Extract and Imipenem against Staphylococcus aureus and Escherichia coli. Mymensingh Medical Journal : MMJ, 25(3), $477-484$.

Silva, L. F. B., Bortoluci, F. \& Vivan, A. C. P. (2019). Análise microbiológica de queijos tipo minas frescal oriundo de diferentes formas de produção. Salusvita, 38(2), 329-343.

Sousa, T. L., Silva, J. P., Vieira, J. N., Rodrigues, L., do Prado Carvalho, T., Viana, L. F., \& Freire, M. C. F. B. (2020). Produção e avaliação microbiológica da vida útil de queijo minas frescal enriquecido com óleo essencial de capim limão. Alimentos: Ciência, Tecnologia e Meio Ambiente, 1(6), 11-23.

Shan, B., Cai, Y. Z., Brooks, J. D., \& Corke, H. (2011). Potential application of spice and herb extracts as natural preservatives in cheese. Journal of Medicinal Food, 14(3), 284-290. https://doi.org/10.1089/jmf.2010.0009

Teixeira, V. T. (2009). Análise sensorial na indústria de alimentos. Revista do Instituto de Laticínio Cândido Tostes, 64(366), 12-21.

Yadav, S., Trivedi, N. A., \& Bhatt, J. D. (2015). Antimicrobial activity of fresh garlic juice: An in vitro study. Ayu, 36(2), $203-207$. https://doi.org/10.4103/0974-8520.175548

Zardast, M., Namakin, K., Esmaelian Kaho, J., \& Hashemi, S. S. (2016). Assessment of antibacterial effect of garlic in patients infected with Helicobacter pylori using urease breath test. Avicenna Journal of Phytomedicine, 6(5), 495-501.

Zocche, F., Bastos, C. P., Bassani, M. T., França, R. C., Lima, A. S. \& Silva, W. P. (2012). Estafilococos coagulase positiva em queijos Minas Frescal e Minas Padrão comercializados em Pelotas, Rio Grande do Sul. Boletim Centro de Pesquisa de Processamento de Alimentos, 30(1), 119-124. 